\title{
Discourse, Identity and Strategy: The Analysis of China's Cultural Diplomacy Based on the Case of Confucius Institutes
}

\author{
Yang Kun* \\ The Institute for Social and Cultural Research \\ Macau University of Science and Technology \\ Macau, China \\ kunyang998@hotmail.com
}

\begin{abstract}
While China's rise in economic and military power, it adjusted its strategic perspective and it has put many new measures in place of which the Confucius Institute is one. Being one of the strategies of cultural diplomacy, Confucius Institute is mainly to improve the soft power of China in the age of globalization. In the paper, the Confucius Institutes will be analyzed from the perspective of post structuralism, that is, the relationships among the discourse of China, the identity of China and Confucius Institutes will be analyzed in details. The implementation of Confucius Institutes caters to the evolving discourse and identity of China.
\end{abstract}

Keywords-Cultural Diplomacy; Confucius Institutes; Post Structuralism; Discourse; Identity; Strategy

\section{INTRODUCTION}

Culture has become recognized as an important factor in international relations. As China's economic and political clout grows, it has recognized the importance of soft power as the country to rise, and therefore it needs to cultivate soft power through cultural diplomacy. In the late 2000s, the National
People's Congress and top leadership began emphasizing cultural diplomacy as a means of promoting Chinese ideas abroad and therefore enhancing the country's soft power.

The central aim of China's contemporary cultural diplomacy is to project the image that China's culture is admirable and that China's intentions are benign. [1] Being one of the strategies of cultural diplomacy, Confucius Institute is mainly to improve the soft power of China in the age of globalization. The implementation of Confucius Institutes caters to the evolving discourse and identity of China.

\section{CONFUCIUS INSTITUTES}

As the importance of culture in foreign policy has become more appreciated, a wide range of cultural diplomacy activities have developed throughout the world. Language institute is one aspect of cultural diplomacy and are compared in the following table taken from a presentation by Don Starr. [2]

TABLE I. LEADING LANGUAGE INSTITUTES

\begin{tabular}{|c|c|c|c|c|}
\hline Name & Foundation date & Branches worldwide & Language/ culture & Aims \\
\hline Alliance Française & 1883 & 1081 in 35 countries & French & $\begin{array}{c}\text { To widen access to French language } \\
\text { and culture }\end{array}$ \\
\hline Goethe Institute & 1925 & 125 in 76 countries & $\begin{array}{c}\text { Promote the study of the study of German } \\
\text { and international cultural exchange }\end{array}$ \\
\hline British Council & 1934 & $150+200$ proposals & English & $\begin{array}{c}\text { Build mutually beneficial relationships between } \\
\text { people of the UK and other countries }\end{array}$ \\
\hline Confucius Institutes & 2004 & 525 in 138 countries & $\begin{array}{c}\text { Mimed at promoting friendly relations with } \\
\text { other countries and enhancing the understanding } \\
\text { of Chinese language and culture }\end{array}$ \\
\hline
\end{tabular}

China has adopted foreign models of cultural diplomacy to produce the Confucius Institutes. The Confucius Institutes were first established in 2004, with the first institute opening in Seoul. The primary goal of these institutions is to promote Mandarin Chinese language learning. Other functions include promoting Chinese culture and developing positive opinions of China within a global setting. Modeled along the lines of Germany's Goethe-Institute and France's Alliance Française and British Council, there are currently 525 Confucius
Institutes and 1113 Confucius Classrooms in 138 countries in 2017. [3]

The Confucius Institutes are nonprofit organizations designed to "satisfy the need of people who are interested in Chinese learning all around the world, promoting the understanding of Chinese culture, enhancing the educational and cultural cooperation between China and the world, developing the friendship between China and other countries, 
to help developing a multicultural environment and building up a harmonious world.” [4] Apart from language classes, the Confucius Institutes organize a wide variety of cultural activities ranging from music, calligraphy, cooking and traditional Chinese medicine to hosting talks on China's economy, history, culture and society. The Confucius Institutes have allowed foreigners to gain a better understanding of China.

The high rate of proliferation of Confucius Institutes means that international audiences are positively receiving a Chinese cultural product that has been carefully crafted, packaged and delivered by the Chinese government.

Through the Confucius Institutes, China tries to improve its international influence. The Confucius Institutes reflect a more confident and effective cultural diplomacy and offer greater opportunities for China to engage in the international stage. The Confucius Institutes aim at promoting Chinese culture and reassuring the world that China's re-emergence will be peaceful.

Cultural diplomacy is a key pillar of China's contemporary foreign policy. Confucius Institute, which is one of brand of China's cultural diplomacy, is designed to reinforce the harmonious relations and enhance the international community's knowledge of China. In the paper, Confucius Institutes will be used as a case study to provide a concrete analysis China's cultural diplomacy.

\section{CUltural Diplomacy}

As China has begun to make economic gains, it has begun to play a greater role in international affairs, and has sought to reassure the rest of the world that its rise as a global power will be peaceful. China's re-emergence as an economic power has been accompanied by concerned that it will be a threat to existing power and the rest of the world, and Chinese elites have become more aware of the damage negative international public image can have on the drive for economic development and stability. [5] In 2003, the peaceful rise theory promoted by Zheng Bijian became influential, who advocated promoting Chinese culture abroad as a means of overcoming hostility and negative images towards China. [6] The peaceful rise strategy regards a peaceful world environment as essential for China's deep social, economic and political reform. [7] Although the Confucius Institutes orientate themselves toward teaching the Chinese language and culture rather than passing on Confucian values, the image of Confucius, an ancient Chinese cultural icon has been chosen to maximize the global appeal of China itself. The Confucius Institutes themselves reflects a new stage of confidence in Chinses cultural diplomacy.

China's cultural diplomacy is evolving towards greater engagement and stability as a prediction for economic development. As China continues its rise as an economic power, the Confucius Institutes are rapidly developing a network to encourage the learning of Chinese and its culture, which may have major implications for China and the rest of the world. China's government considers Confucius Institutes an important element in cultivating a better soft power of China.

With the open and reform policies, Chinese government has become much more sensitive to China's international image, and the Confucius Institutes, a new strategy of cultural diplomacy come up since they accord with the country's attitudes towards foreign relations. In regard to its national image, Chinese government considers cultural diplomacy an essential part of it diplomatic effort to dissolve the China threat theory, and to take advantage of China fever to promote Chinese culture around the world. With the government's launching of its going-out strategy, China's cultural diplomacy has made rapid progress, which is to defuse China's threat.

\section{The ANAlysis of CONFUCIUS InSTITUTES FROM THE PERSPECTIVE OF Post StRUCTURALISM}

\section{A. Post Structuralism}

According to the theory of post structuralism, there are close relationships among discourse, identity and foreign policy. Through discourse, the identity is built and therefore the foreign policy is carried out. At the same time, the implementation of the foreign policy will further strengthen the identity and also the discourse, that is to say, discourse, identity and foreign policy will interrelate one another. In this paper, foreign policy will refer to one of the strategy of cultural diplomacy, which is Confucius Institute. So the relationships among the discourse of China, the identity of China and Confucius Institutes will be analyzed in details from the perspective of the theory of post structuralism.

\section{B. The Discourse of China, The Identity of China and The Strategy of China}

\section{1) The Discourse of China}

Langue and power have always had a close relationship. [8] Langue is one of the most effective tools for spreading culture and a central element in cultural globalization. The langue one speaks is important towards showing how one views the world around them. Considering this deep and close relationship between language and perception, it is strategic for a nation that aspires to great power status to promote its language. As China grows in comprehensive national power, the government makes effort to use cultural power to improve its influences in the world.

Culture is increasingly recognized as having an influence on decision-making at national and international levels. Culture can be viewed as a filter of knowledge through which publics and decision makers make decision. [9] As China has opened up and grown more globally engaged, the country's traditional values have come into contact with world, which has shaped the way China thinks about its role on the world stage. In order to overcome its own weakness of discursive power, China embarked on vigorous cultural diplomacy, a strategy used since ancient times for communicating with the rest of the world. The Confucius Institutes which serves as one of the strategy in China's cultural diplomacy spread quickly nowadays all over the world. China considers culture essential in correcting adverse impressions created by its rapid strategic rise. The Confucius Institutes have played a major role in the global transmission of Chinese culture. With the assistance of Confucius Institutes, a successful cultural diplomacy, more and more foreigners can feel the beauty of Chinese values like Peace and Harmony. 
The current new leadership is also showing signs of pursuing an accommodating and pragmatic cultural policy in keeping with larger national interests of holding high the banner of peace, development, cooperation and mutual benefit. The resolution adopted at the 18th Congress of Communist Party of China in November 2012 was emphatic about upholding China's cultural heritage. The country's cultural soft power should be improved significantly for mutual understanding. The Third Plenum of the 18th Party Congress held in November 2013 offered similar emphasis. China is eager to project itself as a responsible stakeholder in the international community by employing culture. So the discourse of China to the world is that Confucius Institutes are good ways to transmit the Chinese culture, which is mainly telling the world the concept of harmony, referring to friendliness, peace and conciliation. When we apply today's Chinese culture to the international context, it becomes the diplomatic concept of building a harmonious world. Confucian concepts such as harmony are increasingly being used to underpin the current policy's innovation, and promote domestic and global stability.

So China put forward the active strategy of cultural diplomacy, that is, Confucius Institute, which is to build a harmonious world with long-lasting peace and common prosperity. Building a harmonious world could help create a favorable international environment for China's development, and build a positive national image and international prestige. Up to now, in promoting the concept of building a harmonious world, China has utilized cultural diplomacy mainly by establishing the Confucius Institutes all over the world. By the establishment of the Confucius Institutes, China hopes that it will enhance credibility and ease suspicions in China's foreign relations with developed countries; it can cement friendly and cooperative relations with developing countries; and it can win over foreign opinions in those countries that have not yet established diplomatic relations with China. [10]

\section{2) The Identity of China}

China has undergone different eras in its economic development since the revolution in 1949. A significant transformation has been apparent since the open up policy in 1980. In order to adapt to the era of globalization and China has required the adoption of new policies in cultural diplomacy. In recent years, China has emerged as an active player in the international arena, taking a more confident and more constructive approach to regional and global affair. China has been involved in the international system since the rapid development of its economy. The government adjusted the strategic perspective of its cultural diplomacy. The establishment of Confucius Institutes in 2004 is the beginning of a new phase in China's cultural confidence and Confucius Institute is regarded as part of a major Chinese effort in international image management. In the era of globalization, China needs stability in the world system to continue its growth. And Confucius Institute works as an effective way to win more friends and promote the communication.

As China has transformed from a weak economic position in the middle of 20th century to be one of the major global economic powers of the 21st century, its approach to the international system has also transformed. Since 2004, China's cultural diplomacy has become more engaged and cooperative than any time in its history.

It has been more than 30 years since China opened to the outside world. In step with its growing economy, its weight in international affairs has increased, therefore China has changed its previous policies, both domestic and international. China now takes a more proactive role in the international stage.

At the turn of the 21st century, more and more Chinese scholars are turning to traditional Chinese thinking and trying to find similarities and differences between China and Western philosophical traditions to explain Chinese behavior in international relations. [11] China is developing programs like the Confucius Institutes to promote the culture to extend the influence abroad. The attraction of a nation's culture in foreign public opinions can make it easier for the country being represented to meet its foreign policy goals. Soft power has been defined by Joseph Nye as getting what you want with attraction rather coercion or payments. [12] Joseph Nye describes military power, economic power and soft power as three types of powers that nations must use to be effective in the contemporary international system. The resources that produce soft power derive from the culture of the country it originates from, the value a country champions in its behavior at home and abroad and in its domestic and foreign policies, all of which strongly influence the preference of others. Chinese scholars realize that soft power is an element of becoming a global power and the Confucius Institute is one of the strategies of the government's determination to develop its soft power. Chinese intellectuals regard building both hard and soft power as important tasks that China faces if it is to reclaim its status as a global power. Zhao Qizheng, the former director of the State Council Information Office stated that China should regard reviving its culture and strengthening cultural communication with the rest of the world as an important task for the nation's future. [13] While China's rise in economic and military power, its aim to rise in soft power through cultural diplomacy is obvious.

The rise of the overseas Chinese craze is due to the appeal of Chinese culture, but also the increasing practical demand for the Chinese language, occasioned by China's rapid economic development. With the rapid economic development in China, In the course of economic globalization, cultural diplomacy becomes a highlight in international relations. Culture, which is regarded as a new standard to evaluate a country's soft power and an effective approach to enhance a country's international status and influence, is attached great important to by many governments. Cultural diplomacy, a method to coordinate by soft way, has a great influence on soft power and assist the country to establish a good national image to some extent. The role in the world political stage, international relationship, national reputation and its impact depend on the country's cultural diplomacy. [14] China adjusted its strategic perspective and it has put many new measures in place of which the Confucius Institute is one. The identity of China is still a developing country yet it continues to rise to be a greater power in the world. The implementation of the Confucius Institutes meets the demand of the evolving identity of China in the age of globalization. 


\section{3) The Strategy of China}

In his address to the 17th Party Conference in October 2007, President Hu Jintao emphasized the need to build cultural soft power, as a means of promoting domestic harmony and increasing international competition.[15] Cultural diplomacy is to manage the international environment by spreading its cultural resources and facilitating cultural transmission abroad.[16] As nations seek to project their image, they presume that cultural resources can be used to generate social resources and foster trust, cooperation and collaboration.

China does not seek to disrupt the world system or threaten its neighbors while it continues to advance the development of the Confucius Institutes all over the world. In order to fight the foreign hostility, China try to create a more positive image through Confucius Institutes. The fact China is developing the Confucius Institutes is the evidence of its intention to improve its soft power. Confucius Institutes are aimed at influencing foreign public opinions and aimed to tell the world that a rising China will not be threatening, and to allow for further development as a global power.

The Confucius Institutes are not only carrying out Chinese government goals and adhering to Chinese regulations but also improving international influence and image. To some extent, the Confucius Institutes can grow soft power.

\section{The Relationship among Discourse, Identity and Strategy}

In all, The Confucius Institutes represent a package of programs designed to improve China's soft power, and are an example of the language institutes aspect of cultural diplomacy that is part of the public diplomacy that many nations practice in the era of globalization, which is aimed to influence foreign publics.

The discourse of China is to tell the world the concept of harmony, referring to friendliness, peace and conciliation. When we apply today's Chinese culture to the international context, it becomes the diplomatic concept of building a harmonious world. The discourse meets the demand of the identity of China, a country who is aimed to be on peaceful rise in the era of globalization. And The Confucius Institute is a useful component of China's international cultural diplomacy, which works as a strategy to the implement China's discourse to build a harmonious world but also meet the demand of the identity of China, a country who is on peaceful rise and is eager to gain more soft power in the world political stage. The function of Confucius Institutes is to demonstrate to the world the richness of Chinese thought and the value of Chinese culture. The hope is to demonstrate through Confucius Institutes that China is transformed nowadays: it is not it once was. There is also awareness in China that its rapid and expansive transformation provokes fears in the Western countries. Confucius Institutes are meant to mitigate growing fears about China's rise and they work to soften China's image, attempting to make it more enticing than fearful. The Confucius Institute being one of the strategies in the foreign policies, it does promote the identity of China, a country who is gaining more power in economy, military and culture. At the same time, it can also enhance the discourse of China to build a harmonious world.

\section{CONCLUSION}

Language and culture institutes are one aspect of cultural diplomacy, and cultural diplomacy is part of public diplomacy. Such activities are designed to achieve soft power.

The Confucius Institutes are a means to improve China's international influence. China's cultural diplomacy seeks understanding for it policies and political system, and seeks trust and respect.

China has worked hard to establish the Confucius Institutes. Actually the Confucius Institutes can be a tool for engagement between China and the rest of the world. Chinese government has recognized that cultural differences can be a factor in difficulties they have had in the international areas so China has to make effort to improve the skills in communicating their messages in the world with the strategy of cultural diplomacy. It is apparent that China is trying to make the Confucius Institutes acceptable to foreigners and to make its culture and language accessible to them.

The Confucius Institutes reflect a new confidence in China's attitude towards the rest of the world, and a greater opportunity for engagement. Through the Confucius Institutes, China aims to develop the soft power architecture. The Confucius Institutes represent a new confidence and effectiveness in Chinese foreign policy, and one strategy that increases the opportunities for engagement.

Although language institutes differ from country to country in areas such as funding and relationships to their governments, the Confucius Institutes have much more in common with the other language institutes. [17] The Confucius Institute is a useful component of China's international cultural diplomacy which tries to build understanding, respect and trust between different countries, but it still takes time to work. There is still a long way for China to go to improve its soft power in the world political stage, yet the implementation of the Confucius Institutes will enhance credibility and ease suspicions in China's foreign relations with developed countries; it can cement a friendly and cooperative relations with developing countries; and it can win over foreign opinions in those countries that have not yet established diplomatic relations with China. [18] In this way, China hopes to improve its soft power gradually in the world.

It is generally accepted that Confucius Institutes do amount to a form of soft power directed at influencing foreign public opinions to form a positive view about a rising China, and there is a need to recognize that other nations are also involved in similar activities to promote their soft power. [19] Even though Confucius Institute may limit the effectiveness of its cultural diplomacy while its political values are different from the rest of the countries of the world, it is still one of China's effective ways in cultural diplomacies, which is to increase the resonance of Chinese culture throughout the world. And the implementation of Confucius Institutes meets the need of China in its discourse to the world and also it caters to the evolving identity of China in the era of globalization. 


\section{REFERENCES}

[1] Stephen J. Hoare-Vance, The Confucius Institutes and China's Evolving Foreign Policy, University of Canterbury, 2009, pp.71.

[2] Don Starr, "Creating a World Language": Chinese Government Policy and the Confucius Institute Program Viewed from a British Perspective. Paper given at conference: Rising China in the Age of Globalization, University College Dublin, August 16, 2007.

[3] Confucius Institutes,

http://www.hanban.edu.cn/confuciousinstitutes/node_10961.htm, (Accessed July 28, 2018)

[4] Confucius Institutes, "Constitution and Bylaws of the Confucius Institutes,” http://college.chinese.cn/en/article/200908/29/content_22323.htm (Accessed May 16, 2018)

[5] Stephen J. Hoare-Vance, The Confucius Institutes and China's Evolving Foreign Policy, University of Canterbury, 2009, pp31.

[6] Guo, Xiaolin, Repackaging Confucius: PRC Diplomacy and the Rise of Soft Power Institute for Security and Development Policy http://www.isdp.eu/files/publications/ap/08/xg 08repackagingconfucius.p df. (Accessed July 20, 2018)

[7] Guoli Liu, "The Dialectic Relationship between Peaceful Development and China's Reform," in China's "Peaceful Rise" in the 21st Century: Do mestic and International Conditions, ed. Guo Sujian (Hampshire, UK: Ashgate, 2006. pp. 17

[8] Ding, Sheng, and Robert Saunders. "Talking Up China: An Analysis of China's Rising Cultural Power and Global Promotion of the Chinese Language." East Asia 23, no. 2 (2006): 3-33.
[9] Ding, Sheng. The Dragon's Hidden Wings: How China Rises with its Soft Power Plymouth, United Kingdom, Rowman and Littlefield, 2008.

[10] Pan Weijuan: Cultural Dip lo macy and a Harmonious World, CIR, May, 2008.

[11] Song Xinning, "Building International Relations Theory with Chinese Characteristics," Journal of Contemporary China 10, no. 26 (2001) pp. 72.

[12] Nye, Joseph. Soft Power: The Means to Success in World Politics Cambridge, MA, Public Affairs, 2004.

[13] Shen Suru, "Kaizhan 'ruan shili' yu dui wai chuanbo de yanjui” quoted in Soft Power in Chinese Discourse: Popularity and Prospect. pp. 11.

[14] Morgenthau, Politics among Nations, Shanghai Translation Publishing House, 1995.

[15] Xinhua. Hu Jintao Calls for Enhancing 'Soft Power' of Chinese Culture. http://news.xinhuanet.com/english/2007-10/15/content_6883748.htm (Accessed November 24, 2008)

[16] Cull, Nicholas. Public Diplomacy: Taxonomies and Histories. American Academy of Political and Social Science no. 616 (2008): 3154.

[17] Stephen J. Hoare-Vance, The Confucius Institutes and China's Evolving Foreign Policy, University of Canterbury, 2009 pp62.

[18] Pan Weijuan: Cultural Diplomacy and a Harmonious World, CIR, May, 2008.

[19] Stephen J. Hoare-Vance, The Confucius Institutes and China's Evolving Foreign Policy, University of Canterbury, 2009 pp. 21 